leneigenschaften von der Vorkommenshäufigkeit, dem Anteil der Tiere, die als Eltern verwendet werden und von der Zuverlässigkeit der Prüfung abhängt.

Ein numerisches Beispiel zum Gebrauch der Zahlen in den Tabellen wird ebenfalls angegeben.

\title{
HOW TO HANDLE SAMPLING AND SELECTION FOR PRODUCTION AND MANAGEMENT TRAITS IN DAIRY CATTLE
}

\author{
R. D. Politiek. - Department of Animal Production, Agricultural University, Duivendaal 5. \\ Wageningen, The Netherlands.
}

Sampling and selection for production and management traits in dairy cattle is a complex problem. In the scope of modern breeding plans (scheme I) it is stated that only the best $25 \mathrm{p}$. Ioo of the bulls tested on production $(+++10 \mathrm{p}$. Ioo and $++15 \mathrm{p}$. I00) are worthwhile to be ranked according to management traits. A uniform and clear presentation of progeny test results is proposed, namely the breeding value expressed as a deviation from the average ( $\mathrm{kg}$ milk, 305 days, first lactation).

Management traits can be subdivided in categories like reproduction traits (stillbirth, fertility, and so on) milking traits (ease of milking, udder, mastitis) and conformation traits. Accurate sampling is necessary but also a clear and uniform system of handling and classification along the same lines as for production (scheme 2). A final ranking of the top classes (SS and SD) is necessary. A proposal of a sire summary (scheme 3 ) is given. It is worthwhile to study this subject more closely in collaboration with the International Dairy Federation (I.F.D.) to find some general guidelines for handling and selection of production and for management traits.

\section{MANAGEMENT TRAITS IN DAIRY CATTLE : \\ DYSTOCIA, UDDER CHARACTERISTICS RELATED TO PRODUCTION, AND A REVIEW OF OTHER TRAITS}

\section{A. E. Freeman, Iowa State University, Ames, Iowa, U.S.A.}

Primary selection emphasis should be on milk production and milk constituents. Management traits contributing to ease or economy of production should be selected only if economic importance and phenotypic and genetic relationships to productive traits justify such selection.

Breeding efficiency is economically important but genetic improvement within breeds is difficult. Evidence indicates dystocia can be minimized by selecting sires for production, evaluating them for ease of calving, mating heifers to sires whose offspring are born easily without direct selection against dystocia. Selection against mastitis might be effective, but management practices can reduce the incidence of mastitis. Selection for udder and leg structure may be necessary in order to avoid problems concerning economical food production. Speed of milking has economic importance and it responds to selection. The amount of emphasis for the selection of milking speed and the most efficient way to apply this has not been clarified. Additional study of the genetics of body-weight change is necessary in order to maximize feed conversion. Genetic control of metabolic disorders in not now feasible ; management control is necessary. Dairymen desire amenable cows, but heritability estimates for this trait are low. Measures of temperament need improvement. The economic worth of all management traits should be further quantified.

\section{A CHEAP METHOD OF PROGENY TESTING A.I. BULLS} FOR MILK PROTEIN

K. MaIjala AND V. VIlVA. - Agricultural Research Centre, Institute of Animal Breeding, Tikkurila, Finland.

In order to develop a cheap method for progeny testing of bulls for milk protein content and yield, about 16600 milk samples were collected of firstcalving daughters of bulls (I sampledaughter) in I97I-I973. In 197I the protein determinations were made with Promilk in one labo- 
ratory and with 1 RMA in another. In 1972-1973 the samples were investigated with Prot-oMat in two laboratories.

In each year there appeared significant differencies in protein-p. Ioo between laboratories but these grew continuously smaller. These differencies like the effects of days after calving, of average herd milk yield and of month of test day were eliminated with statistical corrections prior to estimating the heritabilities and progeny testing, Daughter's fat-p. roo, milk yield of test day, protein/fat-ratio and fat and protein yields of test day were computed in the same way.

The heritabilities of different traits on the basis of one test day were as follows : milk yield 25 p. I00, fat-p. IOo 28 p. Ioo, protein-p. I00 25 p. Ioo, protein/fat-ratio I 7 p.Ioo, fat yield $2 \mathrm{I}$. roo, protein yield I9 p. Ioo and fat + protein yield $2 \mathrm{I}$ p. Ioo. The estimates varied slightly in each year; it seems that the most reliable estimates were from the year 1973. On the basis of the mentioned heritabilities the number of daughters required for a repeatability of $70 \mathrm{p}$. roo in progeny testing were $35,3 \mathrm{r}, 35.53,42,47$ and 42 respectively. In the number of samples these mean 20-30 p. Ioo of what is needed to reach the same accuracy with a monthly sample of 16 daughters during lactation. Progeny tests based on at least ten daughters were obtained from 136 , 134 and I 56 bulls each year respectively. It seems as though with a relatively small number of samples the progeny testing of bulls can be managed.

In the progeny testing results the correlation of milk yield with fat-p. Ioo was -0.42 , with protein-p. 100 -0.29 , with fat yield $0.8 \mathrm{I}$, and with protein yield $0.9 \mathrm{I}$. The correlation between fat-p. roo and protein-p. roo was 0.44 , and between fat yield and protein yield 0.84 . The genetic correlations calculated from single observations were similar to these both for signs and values.

\section{SERUM ENZYMES AND METABOLITES RELATED WITH HIGH PRODUCTION AND LONGEVITY}

F. Graf, K. Frahm, L. Furtmayr, H. KräUsslich, K. Osterkorn. - Institut für Tierzucht und Tievhygiene dev Ludwig-Maximilians Universität München, Veterinärstr. 22, 8, München 22, $B R D$.

Metabolites and enzymes in the blood which are normally used for clinical diagnoses (total bilirubin, glucose, cholesterol, GOT, CK LDH and LDH-isoenzymes), were regularly determined in a high yielding dairy herd, during all stages of lactation. The correlations between serum levels and the dairy traits were analysed.

What we are really looking for by analysing these correlations is to find indicators for the individual physiological reactions of dairy cows on the stress caused by a very high milk production. We think that physiological differences between high yielding cows do exist. There might be cows with a very stabile organism which easily give a high yield, and others which are suffering much more by the stress caused by the production of the same amount of milk.

The investigations were carried out during a period of two years in the dairy herd of the University of Munich consisting of about roo Holstein-Friesian cows. The average milk yield amounted to $7000 \mathrm{~kg}$ milk per year with $3.87 \mathrm{p}$. Ioo butterfat. Each cow was bled 8 weeks before parturition, I week before parturition, 6-24 hours after parturition, 1, 2, 3, 5 weeks after parturition and afterwards in intervals of 8 weeks. The serum levels of all examined blood constituents were significantly influenced by diseases, age, season and stage of lactation. The influence of diseases was eliminated by only analysing data taken from samples of cows which showed no signs of disease. The influence of season was accounted for by adjustment factors. To avoid biases caused by differences in age and stage of lactation intraclass correlations for different stages of lactation were calculated within age classes.

Numerous significant correlations between the serum levels and the milk yield (milk $\mathrm{kg}, \mathrm{FCM}$, fat-p. Ioo, fat $\mathrm{kg})$ at different stages of lactation were found $(r=0.23-0.6 \mathrm{I})$.

For all parameters, rank correlations were calculated. The ranking was determined by the deviations of the measured serum levels from the regression line relating milk yield and serum level. Significant rank correlations between glucose and GOT, cholesterol and glucose and between GOT and LDH-isoenzymes $\mathrm{I}+2$ were detected.

The correlations between the serum levels of two successive lactations were calculated as measurements of the repeatability of the different parameters. Some parameters showed close correlations. In all stages of lactation glucose had the closest correlations of all the parameters examined (up to 0.997). The serum levels of glucose and cholesterol samples, taken 8 weeks before parturition when they are nearly uninfluenced by the milk yield, were about Io p. Ioo higher in animals selected than in animals culled during second lactation. However, the difference is not significant. The other parameters showed no differences between selected and culled animals. 